\title{
Detection of Aflatoxins in Milk and Feed from Cases of Reproductive Tract Disorders in Cattle and Sheep
}

\author{
Bhupinder Kaur Khosa*, Tejinder Singh Rai, Narinder Singh Sharma \\ and Anil Kumar Arora
}

Department of Veterinary Microbiology, GADVASU, Ludhiana-141004, India

*Corresponding author

\begin{abstract}
A B S T R A C T
Keywords

Brucella, Aflatoxin, PCR, Milk, Feed

Article Info

Accepted:

26 August 2020

Available Online:

10 September 2020

In this study, a total number of 135 samples were collected and out of them 80 samples were from reproductive tract, 25 feed samples and 30 milk samples from cattle and sheep. Samples collected from reproductive tract of cattle and sheep were subjected to bacteriological and fungal examination for isolation and identification. A total of 105 bacterial isolates have been found from 68 primary bacterial cultures out of which 50 isolates $(47.61 \%)$ were found to be Gram-positive and 55 isolates $(50.47 \%)$ were Gramnegative. Out of mixture of gram positive isolates, 31 isolates $(62 \%)$ were confirmed to be Bacillus spp., 14 isolates (28\%) Staphylococcus spp., 3 isolates (6\%) Streptococcus spp. and 2 isolates (4\%) were Arcanobacterium pyogenes. Among all Gram-negative isolates, 3 isolates were found to positive for Brucella abortus, 30 for E. coli, 13 for Klebsiella pneumoniae, 7 for Proteus spp. and 2 for Pseudomonas aeruginosa. Amid abortion specific bacteria, 3 isolates have been confirmed to be positive for Brucella sps. by polymerase chain reaction using genus specific primers. A total of 34 fungal isolates were obtained from 68 fungal cultures, out of which a total of 8 fungal species from 6 genera have been identified. Major proportion of these isolates belong to Aspergillus spp. (41.17\%), followed by Alternaria spp. (26.47\%), Penicillium spp. (8\%), Pithomyces spp. (8\%) and Rhizopus spp. (8\%) and Mucor spp. (5.8\%). and are confirmed by molecular method using genus and species specific primers. Collected 25 feed and 30 milk samples were examined for aflatoxin contamination. A total of four feed samples were found to have aflatoxin contamination above the permissible limit i.e. 30ppb according to Indian standards. The level of aflatoxin contamination in feed samples was in between of $4 \mathrm{ppb}$ and $52 \mathrm{ppb}$. All 30 collected milk samples were tested negative for aflatoxin contamination.
\end{abstract}

\section{Introduction}

Reproductive potency is one of major factors that build the livestock industry financially and animal health-wise well built. The elements effecting reproduction potency of domestic animals have serious influence on the economy of dairy industry producers. The sources of reproductive tract infections like repeat breeding and abortion are many and extent from simple management defects to various diseases because of some various 
factors like physical, chemical, biological and environment factors (Yoo 2010). Reproduction failure occurs due to many causes but infectious causes are the most regularly identified. Infections may occur due to a wide variety of infectious agents like bacteria, virus, fungi and protozoa have direct effect on reproductive tract of cattle and sheep (Wolf-Jäckel et al., 2020). These infectious agents have not only remarkable effects on dairy industry but also affect the human health due to zoonotic potential (Staric et al., 2020). Genital tract infections can occur at any stage but these infections are common after parturition because of opening of cervix and immune compromised condition of uterus (Sheldon et al., 2020). After parturition uterus epithelium is damaged and has debris which supports microbial growth (Konigsson et al., 2002). The damaged physical barrier of cervix, vagina and vulva enhance the entry microbes into the reproductive tract of animal from the outside (Sheldon and Dobson 2004). Infection requires the first step to be established i.e. attachment of the organism on the mucosa followed by penetration of surface epithelium and liberation of toxins that ultimately leads to uterine diseases (Sheldon et al., 2006). Majority of reproductive tract infections caused by bacteria such as Brucella abortus, Brucella melitensis, Brucella ovis, Campylobacter jejuni, C. fetus subsp. fetus, Leptospirainterrogans and Listeria monocytogenes. Some non-specific bacteria like Salmonella subspecies Dublin and others like E. coli, Arcanobacterium pyogenes, Staphylococcus spp., Streptococcus spp., Proteus and Pseudomonas aeruginosa also cause reproductive tract infections (Gani et al., 2008).

Espinel-IngroffA (2009) observed that fungal infections cause wide spread and prevalent mycotic disease in man and animals. These infections are a significant reason of illness and death rate mainly in immune compromised animals. Abortions are caused by fungal infections but not as much as bacterial infections. The most important fungal species responsible for abortions are Aspergillus, Mucor, Absidia and Rhizopus which make up to $60-80 \%$ of total mycotic abortions. Jensen et al., (1991) studied that Aspergillus fumigates constitute the major cause of bovinemycotic placentitis and abortion as it spreads to the placenta. Many researchers have isolated pure cultures of Aspergillus fumigates and A. niger in pure culture from cases of abortion in ewes (Siddique et al., 1976).

Mycotoxins are considered to be the harmful secondary metabolites produced by the growing fungi present in processed food and feed, either in field or during storage. More than 100 species of fungi are known to produce mycotoxins and about 400 secondary metabolites with toxigenic activity are produced by these fungi. These fungi belong to the different genera like Penicillium, Aspergillus, Fusarium and Claviceps (Quinn et al., 1994). About 5-10\% of agricultural products all over the globe are destroyed by fungal which is not suitable for humans and animals consumption (Ephrem Guchi, 2015).Because of inferior drying, storage and post-harvest waste are quite significant in developing countries like India. Fungi are saprophytic in nature present in environment abundantly and germinate on food material and produce mycotoxins under favourable conditions (Brera et al., 1998).

Different types of disease causing mycotoxins include aflatoxin ochratoxins, citrinin, sterigmatocystin, alkaloids, zeralenone etc. out of which aflatoxin is commonly present as contaminants in animal feed. Effects caused by mycotoxins may not be instantly found in ruminants but incidence of decreased fertility or high rate of abortions may happen (Anonymous 2003). 
Aflatoxins are very toxic, carcinogenic as well as mutation causing and teratogenic immunosuppressive metabolites found in fungal spp. like Aspergillus flavus and A. parasiticus and $A$. nomius derivatives of difuranocoumarin. $B_{1}, B_{2}, G_{1}, G_{2}$ these four aflatoxins are considered to be naturally produced aflatoxins and the $B$ and $G$ nomenclature are specific based on their expressionof blue and green fluorescent colours when viewed under UV light on thin layer chromatography plates (Edwards et al 2002). Out of four aflatoxins, aflatoxin $B_{1}$ is most potent carcinogenic and is excreted in milk of lactating animal in the form of aflatoxin $\mathrm{M}_{1}$ that have consumed the $\mathrm{AFB}_{1}$ contaminated feed. Aflatoxin contaminated feed taken by animal for a long time in low doses, they produces slow and continuous damage to the body of animal. The Food and Drug Administration (FDA) limits AFB not more than 20 ppb in lactating dairy feeds and to $0.5 \mathrm{ppb}$ in milk (Regis et al., 2019). Animal taking feed having 30ppb aflatoxin produce milk containing AFB residues above the FDA action level of 0.5 $\mathrm{ppb}$. Aflatoxicosis results in reduced feed efficiency, lactation yield, diminish the disease resistance and also can interfere with acquired immunity due to vaccination in livestock and thus making them more prone to various diseases (Diekman and Green, 1992). The purpose of this study was to observe the post effect of aflatoxin contamination in feed given to the animals suffering from reproductive tract disorders.

\section{Materials and Methods}

\section{Sampling}

\section{Reproductive tract samples}

A total 80 samples of reproductive tract disorders consisting of vaginal mucus, cervical mucus, uterine discharges, aborted foetus stomach contents, placenta were taken from cattle and sheep having reproductive tract disorders such as abortion, retained placenta, repeat breeding, anoestrus, pyometra, metritis and endometritis. Based on clinical signs and history of animals, samples were collected in a sterile sample container from different dairy farms in Ludhiana, Punjab as well as the reproductive tract cases of cattle coming in GADVASU clinical complex and adjoining areas of Punjab. Samples were processed for bacterial and fungal isolation by inoculating on suitable media and studying their cultural/colonial characteristics. Samples were stored at $4^{\circ} \mathrm{C}$ until processed, if processing had to be delayed.

\section{Feed and milk samples}

The feed and milk samples collected from same farm where the clinical samples of reproductive tract disorders were collected. These samples were collected in and adjoining areas of Punjab. The total of 25 feed samples were processed for presence of aflatoxin by Pressure Mini Column method which was detected by visual method of measuring the intensity of fluorescence under UV chamber at a wavelength of $365 \mathrm{~nm}$. The feed samples were further processed for quantification of aflatoxin using an improved aflatoxin detection kit devised by charms sciences USA, provided by JC Bioage, Hyderabad. Total 30 milk samples were processed for presence of aflatoxins by qualitative method using Charms SL Aflatoxin $\mathrm{M}_{1}$ Test.

\section{Molecular detection of the isolates}

Genus specific Polymerase Chain Reaction (PCR) for confirmation of Brucella isolates from clinical samples

Brucella isolates were confirmed by using genus specific PCR primersB4/B5 (Bailey et 
al., 1992) (Table 1 and 2). Colonies from inoculated clinical samples were taken and used for DNA isolation. These colonies were earlier subjected to various biochemical tests for confirmation of Brucella.

\section{Extraction of genomic DNA}

Genomic DNA from B. abortus strain 19 and clinical isolates were extracted by hot-cold lysis method (Dashti et al., 2009). $500 \mu \mathrm{l}$ of normal saline solution was taken in an Eppendorf tube. Suspected colonies were taken and suspended in tube and mixed properly with normal saline solution. Tube was closed and subjected to $100^{\circ} \mathrm{C}$ in a dry bath apparatus for 10 minutes. After this incubation, tube was transferred immediately to $-20^{\circ} \mathrm{C}$ to give a temperature shock. Tubes were kept in cold temperature for 30 minutes. The contents of tube were then mixed properly by pipetting the contents of tube in and out. The DNA obtained was used in further molecular work.

\section{Standard/Reference strains}

B. abortusS19 and B. abortus S99 available in Department of Veterinary Microbiology, GADVASU, Ludhiana, and (Punjab) were used as reference strains for molecular work. These isolates were preserved by regular subculturing after every 15 days on BSM plates.

\section{PCR protocol (B4/B5)}

PCR reaction mixture was prepared for one reaction in a volume of $25 \mu 1$ containing $12.5 \mu \mathrm{l}$ master mix, $1 \mu 1$ forward primer, $1 \mu \mathrm{l}$ reverse primer, $5.5 \mu 1$ nuclease water, $5 \mu 1$ of template DNA. PCR cycling conditions are depicted in Table 3 and consisted of initial denaturation at $94^{\circ} \mathrm{C}$ for $5 \mathrm{~min}$, followed by 35 cycles each of $94^{\circ} \mathrm{C}$ for $1 \mathrm{~min}$ (denaturation), $65^{\circ} \mathrm{C}$ for $1 \mathrm{~min}$ (annealing) and $72^{\circ} \mathrm{C}$ for $1 \mathrm{~min}$ (extension) and a final extension of $72^{\circ} \mathrm{C}$ for $10 \mathrm{~min}$.

\section{Analysis of PCR product}

The PCR product were evaluated by gel electrophoresis using $1 \%$ agarose gel in $1 \mathrm{X}$ TBE buffer containing ethidium bromide at $90 \mathrm{~V}$ for 1 hour and visualized under Alpha Imager 3400HP Gel Documentation System and photographed Fig. 1.

\section{Molecular detection of Aspergillus spp.}

Polymerase chain reaction (PCR) for confirmation of Aspergillus isolates from clinical samples

\section{Extraction of fungal DNA from fungal cultures}

The DNA was extracted from fungal cultures suspected to be Aspergillus as well as from standard cultures by Chloroform Isoamyl alcohol method (Moller et al 1992) using liquid nitrogen. A volume of 30-60 mg of mycelia was ground quickly in $50 \mathrm{ml}$ liquid nitrogen in sterilized pestle and mortar for extraction of DNA. The powdered mycelia were rinsed with a volume of $500 \mu \mathrm{l}$ of TES buffer and collected in an Eppendorf tube. A volume of $3.5 \mu \mathrm{l}$ of Proteinase $\mathrm{K}$ was added and tube was kept at $60^{\circ} \mathrm{C}$ for $1 \mathrm{~h}$ with gentle mixing. A volume of $140 \mu \mathrm{l}$ of $\mathrm{NaCl}$ solution along with $65 \mu \mathrm{l}$ of $\mathrm{CTAB}$ was added to it and incubates at $65^{\circ} \mathrm{C}$ for 10 minutes. $700 \mu \mathrm{l}$ of Chloroform-Isoamyl alcohol solution was added and mixed gently. Then tube was incubated at $0^{\circ} \mathrm{C}$ for 30 minutes and was centrifuged at $14000 \mathrm{~g}$ for 10 minutes at $4^{\circ} \mathrm{C}$. The supernatant was transferred to a fresh Eppendorf tube to which $225 \mu \mathrm{l}$ of $5 \mathrm{M}$ ammonium acetate was added. It was mixed gently and place on ice for 30 minutes. The tube was centrifuged at $14000 \mathrm{~g}$ for 10 minutes at $4^{\circ} \mathrm{C}$. $510 \mu \mathrm{l}$ of ice cold isopropanol alcohol was added to an Eppendorf tube and supernatant was also transferred to this tube for precipitating DNA. Then tube was 
centrifuged at $14000 \mathrm{~g}$ for 5 minutes at $4^{\circ} \mathrm{C}$. DNA lumps become visible as pellet and supernatant was drained off.

The pellet was washed twice with chilled $70 \%$ ethanol and was made air dried. The pellet was reconstituted in $50 \mu \mathrm{l}$ TE buffer. $1 \mu \mathrm{l}$ RNase stock solution was added and tube was incubated at $37^{\circ} \mathrm{C}$ for 45 minutes before storing it at $-20^{\circ} \mathrm{C}$.

\section{Primers Used}

\section{Analysis of PCR product}

The amplified product were analyzed by gel electrophoresis at $80 \mathrm{~V}$ for 1 hour in $1 \%$ agarose gel in $1 \mathrm{X}$ TBE buffer containing ethidium bromide and visualized under Alpha Imager 3400 HP Gel Documentation System and photographed figure 2, 3 and 4 .

\section{Detection of aflatoxin in feed and milk}

\section{Feed analysis through PMC}

Each feed sample $(10 \mathrm{~g})$ was taken in a conical flask and $50 \mathrm{ml}$ acetone water was added to it. Then it was shaked on orbital shaker for 30 minutes. The solution was filtered using WFP No. 1.filterate was taken in large test tube and equal volume of $20 \%$ lead acetate solution was added to it and it was mixed thoroughly for $3 \mathrm{~min}$. it was again filtered through WFP No. 1.

Then $2 \mathrm{ml}$ benzene was added to the filtrate and mixed thoroughly and was allowed to stand for 2 min. upper layer was collected in another tube containing $400 \mathrm{mg}$ of natural alumina, mixed and allowed to stand for 2 min. The detected aflatoxins were quantitated by aflatoxin quantitation kit using a strip method base on lateral flow assay principle provided by Charm Sciences, USA which could detect total aflatoxin present in feed. This kit has detection range of $0-150 \mathrm{ppb}$.

\section{Qualitative detection of aflatoxin in milk}

The Charm SLAflatoxin M1 Test (SLAFM) provides quick and exact results using ROSA® (Rapid One Step Assay) lateral flow technology. SLAFM facilitates dairies and food manufacturers to observe the level Aflatoxin M1 at $350 \mathrm{ppt}$ in raw, mixed cow milk. This qualitative test provides a useful method for customers where a fast screening test is needed and Achieves results in 3 minutes.

\section{Results and Discussion}

A total of 80 samples of reproductive tract of cattle and sheep were collected out of which 68 yielded 105 isolates of bacteria and 30 isolates of fungi. The bacteria isolated from samples were Brucella abortus, E. coli, Arcanobacterium pyogenes, Bacillus spp., Klebsiella pneumoniae, Staphylococcus spp., Streptococcus spp., Pseudomonas aeruginosa with incidence of $2.80 \%, 28.57 \%, 1.90 \%$, $29.52 \%, \quad 12.38 \%, \quad 13.34 \%, \quad 2.8 \%, 1.90 \%$ respectively (Table 4 and 5). Out of 80 samples only 30 samples yielded 34 isolates of fungi of which 10 were Alternaria spp., 14 Aspergillus spp., 2 Mucor spp., 3 Rhizopus spp., 3 Penicilliumspp., 3 Pithomyces spp. (Table 6).

A total 30 milk samples were tested for detection of aflatoxin. All of 30 samples were found negative for aflatoxin.

Reproductive tract infections constitute the most important problem causes great economic implications in terms of milk yield, meat production, wool production and fertility of animals. 
Table.1 Sequence of primers used for detection of genus Brucella

\begin{tabular}{|l|l|l|c|c|}
\hline $\begin{array}{l}\text { Name of } \\
\text { primers }\end{array}$ & Gene & Sequence $\left.\mathbf{( 5}^{\prime}-\mathbf{3}^{\prime}\right)$ & $\begin{array}{c}\text { Size of } \\
\text { amplified } \\
\text { product }\end{array}$ & Reference \\
\hline B4 & $b c s p 31$ & TGG CTC GGT TGC CAA TAT CAA & $\mathbf{2 2 3}$ bp & Bailey et al (1992) \\
\hline B5 & & CGC GCT TGC CTT TCA GGT CTG & & \\
\hline
\end{tabular}

Table.2 Sequence of primers used in nested PCR of 18 rRNA gene in Aspergillus spp.

\begin{tabular}{|c|c|c|c|c|}
\hline $\begin{array}{l}\text { S. } \\
\text { no. }\end{array}$ & Primers & $\begin{array}{l}\text { Sequence } \\
\left(5^{\prime}-3^{\prime}\right)\end{array}$ & $\begin{array}{c}\text { Size of } \\
\text { amplified } \\
\text { product }\end{array}$ & Reference \\
\hline \multirow[t]{2}{*}{1.} & ASAP1 & CAG CGA GTA CAT CAC CTT GG & \multirow[t]{2}{*}{$521 \mathrm{bp}$} & \multirow{6}{*}{$\begin{array}{l}\text { Sugita, et al } \\
\quad(2004)\end{array}$} \\
\hline & ASAP2 & CCA TTG TTG AAA GTT TTA ACT GAT T & & \\
\hline \multirow[t]{2}{*}{2.} & ASPU & ACT ACC GAT TGA ATG GCT CG & \multirow[t]{2}{*}{ 190bp } & \\
\hline & $\mathrm{F} 12 \mathrm{r}$ & TTC ACT AGA TCA GAC AGA GT & & \\
\hline \multirow[t]{2}{*}{3.} & ASPU & ACT ACC GAT TGA ATG GCT CG & \multirow[t]{2}{*}{$300 \mathrm{bp}$} & \\
\hline & Af3r & CAT ACT TTC AGA ACA GCG TTC A & & \\
\hline
\end{tabular}

Table.3 Cycling reaction for first step PCR reactions

\begin{tabular}{|l|l|c|c|c|}
\hline Stage & Step & Temperature $\left({ }^{\circ} \mathbf{C}\right)$ & Duration & No. of cycles \\
\hline 1. & Initial Denaturation & 94 & $4 \mathrm{~min}$ & 1 \\
\hline \multirow{2}{*}{ 2. } & Denaturation & 94 & $1 \mathrm{~min}$ & \\
\cline { 2 - 5 } & Annealing & 55 & $2 \mathrm{~min}$ & 30 \\
\hline \multirow{2}{*}{3.} & Extension & 72 & $1 \mathrm{~min}$ & \\
\cline { 2 - 5 } & Final Extension & 72 & $10 \mathrm{~min}$ & 1 \\
\hline
\end{tabular}

Table.4 Cycling reactions for nested PCR reactions

\begin{tabular}{|l|l|c|c|c|}
\hline Stage & Step & Temperature $\left({ }^{\circ} \mathbf{C}\right)$ & Duration & No. of cycles \\
\hline \multirow{2}{*}{ 1. } & Initial Denaturation & 94 & $4 \mathrm{~min}$ & 1 \\
\hline \multirow{2}{*}{. } & Denaturation & 94 & $1 \mathrm{~min}$ & \\
\cline { 2 - 4 } & Annealing & 60 & $1 \mathrm{~min}$ & 25 \\
\hline \multirow{2}{*}{ 3. } & Extension & 72 & $15 \mathrm{~min}$ & \\
\cline { 2 - 5 } & Final Extension & 72 & $10 \mathrm{~min}$ & 1 \\
\hline
\end{tabular}


Table.5 Bacteria isolated from reproductive tract of cattle and sheep

\begin{tabular}{|c|c|c|c|c|c|}
\hline S. No. & Bacteria isolated & \multicolumn{4}{|c|}{ Number } \\
\hline 1. & Arcanobacterium pyogenes & \multicolumn{4}{|c|}{2 (from mixed cultures) } \\
\hline \multirow[t]{4}{*}{2.} & Bacillus & \multirow{4}{*}{31} & \multirow{3}{*}{ Pure } & \multirow{3}{*}{15} & $\begin{array}{l}\text { B. licheniformis } \\
\text { (3) }\end{array}$ \\
\hline & & & & & B. cereus (2) \\
\hline & & & & & Other spp. (12) \\
\hline & & & Mixe & & 16 \\
\hline 3. & Brucella & \multicolumn{4}{|c|}{3 (all pure growths) } \\
\hline \multirow[t]{2}{*}{4.} & E. coli & \multirow[b]{2}{*}{30} & Pure & & 5 \\
\hline & & & Mixes & & 25 \\
\hline \multirow[t]{2}{*}{5.} & Klebsiella pneumonia & \multirow[t]{2}{*}{13} & Pure & & 2 \\
\hline & & & Mixe & & 11 \\
\hline 6. & Proteus spp. & \multicolumn{4}{|c|}{7 (all from mixed growths) } \\
\hline \multirow[t]{2}{*}{7.} & Pseudomonas aeruginosa & \multirow{2}{*}{2} & \multirow{2}{*}{\multicolumn{2}{|c|}{$\begin{array}{l}\text { Nure } \\
\text { Pured }\end{array}$}} & 1 \\
\hline & & & & & 1 \\
\hline 8. & Staphylococcus spp. & \multicolumn{4}{|c|}{14 (all from mixed growths) } \\
\hline \multirow[t]{2}{*}{9.} & Streptococcus spp. & \multirow[t]{2}{*}{3} & Pure & & 1 \\
\hline & & & Mixe & & 2 \\
\hline
\end{tabular}

Table.6 Fungi isolated from reproductive tract of cattle and sheep

\begin{tabular}{|c|c|c|c|c|c|}
\hline \multirow{2}{*}{$\begin{array}{l}\text { S. no. } \\
1\end{array}$} & \multirow{2}{*}{\multicolumn{2}{|c|}{ Fungal isolates obtained }} & \multicolumn{3}{|c|}{ Number } \\
\hline & & & \multirow[b]{2}{*}{9} & Pure & 5 \\
\hline & & & & Mixed & 4 \\
\hline \multirow[t]{5}{*}{2} & \multirow{5}{*}{$\begin{array}{l}\text { Aspergillus spp. } \\
\text { (total =14) }\end{array}$} & \multirow[t]{2}{*}{ A. flavus } & \multirow[t]{2}{*}{5} & Pure & 3 \\
\hline & & & & Mixed & 2 \\
\hline & & A. fumigatus & \multicolumn{3}{|c|}{4 all pure growths were obtained } \\
\hline & & \multirow[t]{2}{*}{ A. niger } & \multirow[t]{2}{*}{5} & Pure & 2 \\
\hline & & & & Mixed & 3 \\
\hline \multirow[t]{2}{*}{3} & \multirow{2}{*}{\multicolumn{2}{|c|}{ Mucor spp. }} & \multirow[t]{2}{*}{2} & Pure & 1 \\
\hline & & & & Mixed & 1 \\
\hline 4 & \multicolumn{2}{|l|}{ Rhizopus spp. } & \multicolumn{3}{|c|}{3 pure cultures were obtained } \\
\hline 5 & \multicolumn{2}{|l|}{ Penicillium spp. } & \multicolumn{3}{|c|}{3 pure growth culture were obtained } \\
\hline 6 & \multicolumn{2}{|l|}{ Pithomyces spp. } & \multicolumn{3}{|c|}{3 pure growth culture were obtained } \\
\hline
\end{tabular}


Table.7 Amount of aflatoxins present in feed samples

\begin{tabular}{|c|c|c|}
\hline $\begin{array}{l}\text { Feed sample } \\
\text { number }\end{array}$ & $\begin{array}{l}\text { Amount of aflatoxin } \\
\text { detected/interpretation }\end{array}$ & $\begin{array}{l}\text { Clinical samples } \\
\text { correspondence to feed }\end{array}$ \\
\hline F1 & 48 ppb (above limit) & $\mathrm{S} 1, \mathrm{~S} 2$ \\
\hline F2 & $20 \mathrm{ppb}$ (below limit) & S7 \\
\hline F3 & $24 \mathrm{ppb}$ (above limit) & S 12 \\
\hline F4 & 26 ppb (above limit) & S 13, S14 \\
\hline F5 & $22 \mathrm{ppb}$ (above limit) & S $18-$ S 20 \\
\hline F6 & $30 \mathrm{ppb}$ (above limit) & S 21 \\
\hline F7 & 15 ppb (below limit) & S 22 \\
\hline F8 & 4 ppb (below limit) & $\mathrm{S} 23, \mathrm{~S} 24$ \\
\hline F9 & 15 ppb (below limit) & S25 \\
\hline F10 & $16 \mathrm{ppb}$ (below limit) & S 26 \\
\hline F11 & $20 \mathrm{ppb}$ (below limit) & S 27 \\
\hline F12 & $16 \mathrm{ppb}$ (below limit) & S 28 \\
\hline F13 & $10 \mathrm{ppb}$ ( below limit) & S 29 \\
\hline F14 & 9 ppb (below limit) & S 36 \\
\hline F15 & $52 \mathrm{ppb}$ (above limit) & S $37-$ S 43 \\
\hline F16 & $6 \mathrm{ppb}$ (below limit) & S 45 \\
\hline F17 & $32 \mathrm{ppb}$ (above limit) & S 47 \\
\hline F18 & 8 ppb (below limit) & S 50- S 61 \\
\hline F19 & $25 \mathrm{ppb}$ (above limit) & S 64 \\
\hline F20 & 5 ppb (below limit) & S 70 \\
\hline F21 & 20 ppb (below limit) & S72 \\
\hline
\end{tabular}

Fig.1 Electrophoresis analysis of PCR product of amplified Brucella abortus

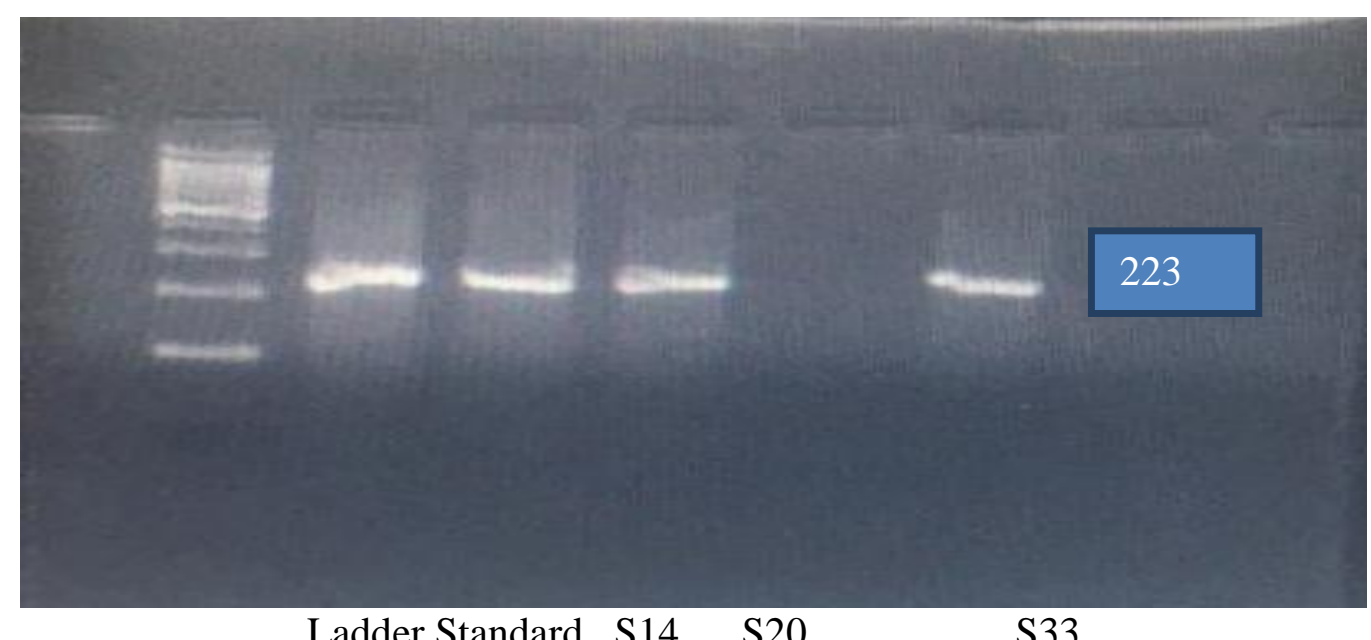

$\begin{array}{llll}\text { Ladder Standard } & \text { S14 } & \text { S20 } & \text { S33 }\end{array}$ 
Fig.2 Electrophoresis analysis of PCR product of amplified Aspergillus genus

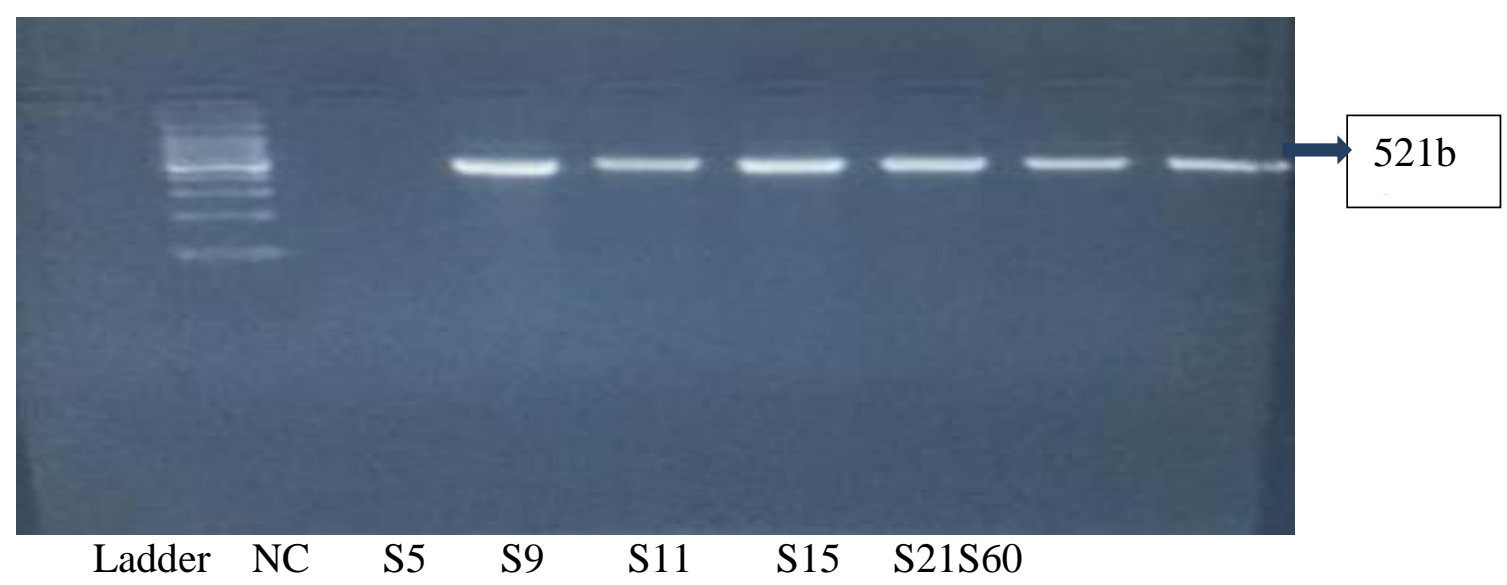

Fig.3 Electrophoresis analysis of nested PCR product of amplified A. flavus

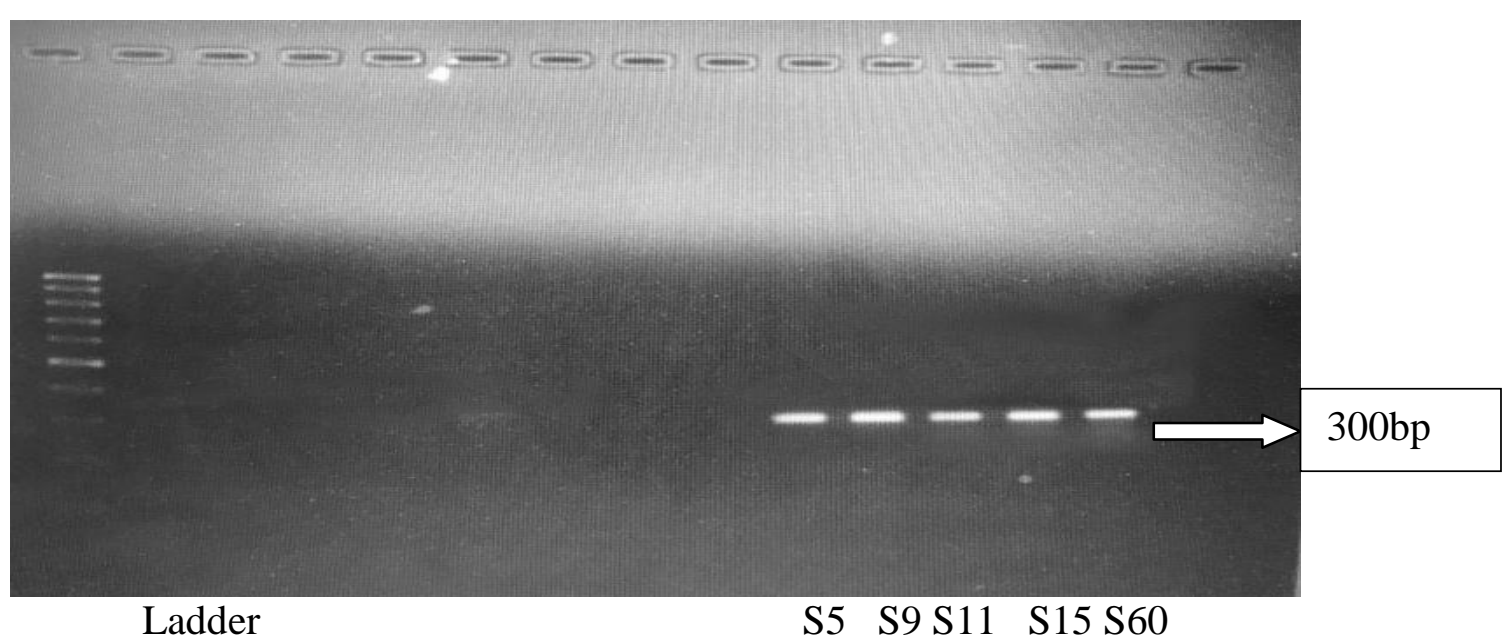

Fig.4 Electrophoresis analysis of nested PCR product of amplified A. fumigatus

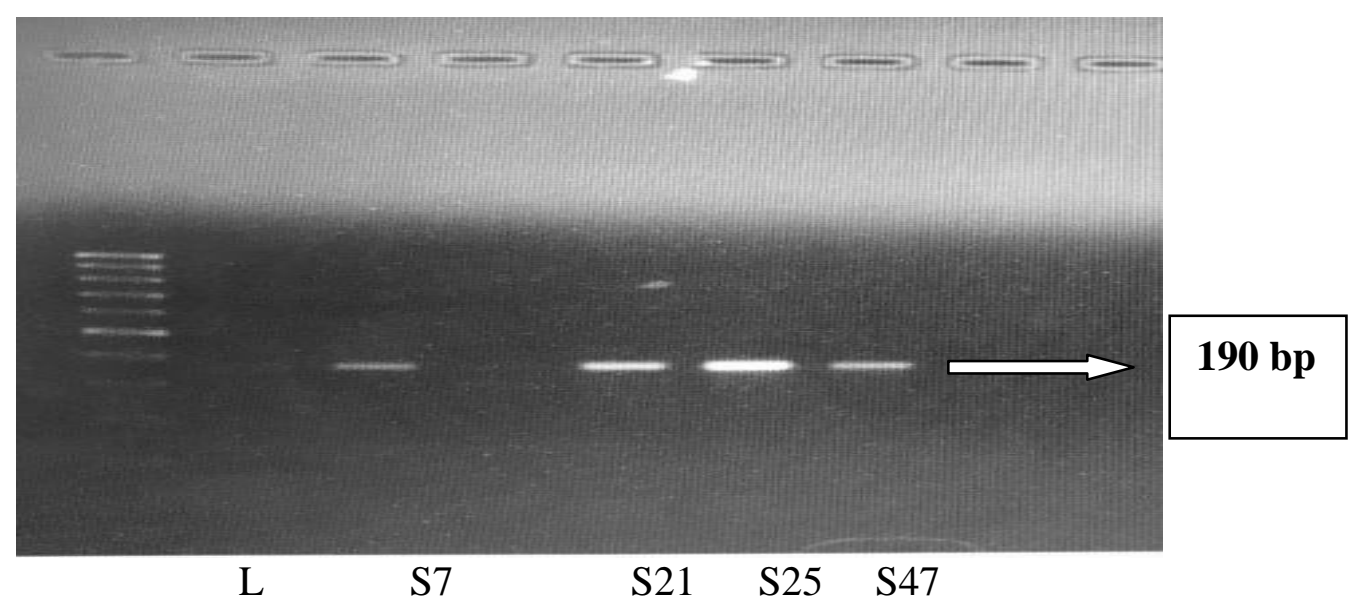


Bacteria and fungi were usually associated with reproductive tract infections of cattle and sheep. In this study, the bacteriological and mycological examination of reproductive tract infections (80) of cattle and sheep revealed that 68 samples yielded 105 isolates and 34 isolates of fungi. From the bacteriological examination E. coli and Bacillus spp. were mostly isolated from cases of pyometra, metritis and retention of placenta in cattle and sheep with the incidence of $28.57 \%$ and $29 \%$ respectively. Other bacteria like Staphylococcus spp., Klebsiella pneumoniae, Proteus spp., Brucella abortus Streptococcus spp., Arcanobacterium pyogenes, Pseudomonas aeruginosa with the incidence of $13.3 \%, 12.3 \%, 6.6 \%, 2.8 \%, 2.8 \%, 1.90 \%$, $1.90 \%$ respectively. Another worker Paisley et al., (1986) stated that toxic puerperal metritis caused by E. coli, Streptococcus spp., Staphylococcus spp. and Pseudomonas spp. and can be isolated from such cases of reproductive infections. In another study conducted by Ghanem et al., (2015), E. coli was identified in association with Streptococcus pyogenes from post-partum dairy cows. Mshelia et al., (2014) investigated bacterial infections of reproductive tract of ewes in tropical arid zone of Nigeria. The samples from vagina and uterus were collected and cultured using standard bacteriological techniques. The findings of the study revealed that the isolates were Escherichia coli (32\%), Staphylococcus spp. (26\%), Klebsiella spp. (16\%), Pseudomonas (15\%) and Proteus (11\%); wherein E. coli and $S$. aureus were the most common bacterial isolates. The bacterial population in the vagina $(64 \%)$ was significantly higher than that in the uterus (34\%).

On mycological examination Aspergillus spp. and Alternaria spp. were mostly isolated from the infections of reproductive tract of cattle and sheep with incidence of $41.17 \%$ and $26.47 \%$ respectively. Other fungal species like Mucor spp., Rhizopus spp., Penicillium spp. and Pithomyces spp. with incidence of $5.8 \%, 8 \%, 8 \%$ and $8 \%$ respectively. A study conducted by Hassan et al., (2012) reported isolation of a total of 20 fungal species related to 8 genera from 25 samples of vaginal swabs collected from cases of cow which suffered from abortion. The main recovered genera of fungi were Aspergillus spp. (80\%), Fusarium spp. (16\%), Penicillium spp. (32\%), Alternaria spp. (8\%) and Candida albicans (40\%) which is similar to present study which results in isolation of 8 fungal species from 6 genera from 30 different reproductive disorders. Here, genera isolated were Alternaria spp. (26.47\%), Aspergillus spp. (41.17\%), Mucor spp. (5.8\%), Penicillium spp. (8\%), Pithomyces spp. (8\%) and Rhizopus spp. (8\%).

A total 25 samples tested for detection of aflatoxin, 21 feed samples were found to be contaminated with aflatoxin. Out of which four feed samples had mean concentration $40.5 \mathrm{ppb}$ of aflatoxin which is higher than Indian Standards. Similar studies were done by Dhand et al., 1998 in dairy cattle feed and reported that $75 \%$ of feed samples were contaminated with aflatoxins. Findings of present study are also in concurrence with other reports by Sarathchandra and Murlimanohar (2013) and Kotinagu et al., (2015) where aflatoxins were found to be widely distributed in feedstuffs. A total 30 milk samples were collected from the same animals from which reproductive tract specimen and feed samples were taken and examined for detection of aflatoxin in milk. All of 30 milk samples were found negative for contamination of aflatoxin in milk of cattle and sheep.

\section{References}

Anonymous. (2003). Mouldy feed and reproduction failure in cows. A report 
by ministry of Agriculture, Food and Rural Development, Alberta.

Bailey G C, Kraah J B, Drassar B S and Stokeer N G. (1992). Detection of Brucella melitensis and Brucella abortus by DNA amplification. Journal of Tropical Medicine and Hygiene .95:271-75.

Brera, C, Miraglia M, Colatosti M. (1998). Evaluation of the impact of mycotoxins on human health: sources of errors. Microchemical Journal.5: 45-49.

Dashti, A A, Jadaon M M, Addulsamad A M and Dasthi H M (2009). Heat treatment of Bacteria: A Simple Method of DNA Extraction for molecular Techniques. Kuwait Medical Journal. 41(2): 11722.

Dhand N K, Joshi D V and Jhand S K. (1998). Aflatoxins in dairy feed/ingredients. Indian journal of Animal Nutrition. 15(4): 285-86.

Diekman, M A and Green M L. (1992). Mycotoxins and reproduction in domestic livestock. Journal Animal Science. 70(5):1615-27.

Edwards, S G, Callghan J, Dobson A D W. (2002). PCR-based detection and quantification of mycotoxigenic fungi. Mycological Research. 106: 1005-25.

EphremGuchi, (2015). Implication of aflatoxin contamination in agricultural products. American Journal of Food and Nutrition. 3:12-20.

Espinel-Ingroff A. (2009). Novel antifungal agents, targets or therapeutic strategies for the treatment of invasive fungal diseases: a review of the literature (2005- 2009). Revistalberoamericana De Micología. 26 (1):15-22.

Gani, M O, Amin M M, Alam M G S, Kayesh M E H, Karim M R, Samad M A, Islam M R. (2008). Bacterial flora associated with repeat breeding and uterine infections in dairy cows.
Bangladesh Journal Veterinary Medicine.6 (1): 79-86.

Ghanem, M, Tezuka E, Devkota B, Izaike Y and Osawa T. (2015).Persistence of uterine bacterial infection, and its association with endometritis and ovarian function in postpartum dairy cows. Journal of Reproduction and Development61(1): 54-60.

Hassan, A A, Mansour M K, El Shafei H M, Oraby N H A and Sayed El Ahl R M H. (2012). Studies on mycosis and mycotoxins in cattle. Bulletin of Environment, Pharmacology and Life Sciences. 1(3): 23-31.

Jensen, H E, Krogh H V, Schonheyder H. (1991).Bovine mycotic abortion-a comparative study of diagnostic methods. Zentralbl Veterinarmed B.38:33-40.

Konigsson, K, Gustafsson $\mathrm{H}$, and Kindahl H. (2002).15-ketodihdro-PGF2 $\alpha$, progesterone and uterine involution in primiparous cows with induced retained placenta and post partial endometritis. Reproduction in Domestic Animals.37: 43-51.

Kotinagu, K, Mohanamba T and Kumari L R. (2015). Assessment of aflatoxin B1 in livestock feed and feed ingredients by high-performance thin layer chromatography. Veterinary World. 8(12): 1396-99.

Moller, E M, Bahnweg G, Sandermann and Geiger H. (1992). A simple and efficient protocol for isolation of high molecular weight DNA from filamentous, fruit bodies and infected plant tissues. Nucleic Acids Research. 20: 6115-16.

Ndagijimana, R, Shahbaz $U$ and Sun X. (2019). Aflatoxin B1 in Food and Feed: An Overview on Prevalence, Determination and Control Tactics. Journal of Academia and Industrial Research.8: (8). 
Paisley, L G, Mickelsen W D and Anderson P B. (1986). Mechanism and therapy for retained fetal membranes and uterine infections of cows: a review. Theriogenology.25: 353-81.

Quinn, P J, Carter M E, Markey B and Carter G R. (1994). Clinical Veterinary Microbiology pp261-66, Mosby Harcourt Publishers Limited.;

Sarathchandra, G and Murlimanohar B. (2013). Occurrence of mycotoxins in livestock feeds and feed stuff of Tamil Nadu. Journal of Environmental Biology. 34(4): 825-30.

Sheldon I M and Dobson H. (2004). Postpartum uterine health in cattle. Animal Reproduction Science. 82-83: 295-306.

Sheldon, I M, Lewis G S, LeBlance S J, Gilbert R O. (2006). Defining postpartum uterine disease in cattle. Theriogenology. 65: 1516-30.

Sheldon, I M, Molinari P C C, Ormsby T J R, Bromfield J J. (2020). Preventing postpartum uterine disease in dairy cattle depends on avoiding, tolerating and resisting pathogenic-bacteria. Theriogenology.
Siddique, I H, Grant G R, Blackwell J G Mckenzie B E. (1976). Organisms associated with abortions and reproductive problems in cattle. Modern Veterinary Practice. 57 (10): 809-11.

Staric, J, Hodnik J J, Staric K D, Jezek J, Holcer N J, Leppala J and Rautiainen R. (2020). Safety culture regarding zoonoses on domestic ruminant farms. VETERINARSKA STANICA. 51 (2): 199-206.

Sugita, C, Makimura K, Uchida K, Yamaguchi H and Nagai A. (2004). PCR identification system for genus Aspergillus and three major pathogenic species: Aspergillus fumigatus, A. flavus and A. niger. Medical Mycology. 42: 433-37.

Wolf-Jäckel, G A, Hansen M S, Larsen G, Holm E, Agerholm J S \& Jensen T K .(2020). Diagnostic studies of abortion in Danish cattle 2015-2017. ActaVeterinariaScandinavica.62.

Yoo, H S. (2010. Infectious causes of reproductive tract infections in cattle. Journal of Reproduction and Development 56: 53-60.

\section{How to cite this article:}

Bhupinder Kaur Khosa, Tejinder Singh Rai, Narinder Singh Sharma and Anil Kumar Arora. 2020. Detection of Aflatoxins in Milk and Feed from Cases of Reproductive Tract Disorders in Cattle and Sheep. Int.J.Curr.Microbiol.App.Sci. 9(09): 3540-3551. doi: https://doi.org/10.20546/ijcmas.2020.909.439 